\title{
Effect of Pre-Treatments and Additives on the Improvement of Cement Wood Composite: A Review
}

\author{
Fatima Z. Brahmia,* Péter György Horváth, and Tibor L. Alpár \\ Cement wood composites (CWC) are a popular construction material. \\ Lightweight or panel-wise wood-based buildings have a growing market in \\ central Europe. Requirements and regulations on both the global and \\ national level are forcing continuous developments. This paper \\ summarizes the research achievements in improving the hygroscopic and \\ mechanical properties and shortening the manufacturing time of CWC via \\ pre-treatments and additives. In addition, new perspectives on enhancing \\ its fire resistance properties by using fire retardant pre-treatments are \\ discussed. CWC without any pre-treatment is a material within the B-s1, \\ d0 category of fire resistance. Using fire retardants could upgrade it to the \\ category $A_{1}$ but the fire retardants should not affect the primary properties \\ of CWC. There are a number of potential fire retardants of wood that may \\ be used, such as phosphorus, boron, and magnesium compounds.
}

\begin{abstract}
Keywords: Cement; Wood; Curing agents; Additives; Treatment; Fire retardants; Inhibitors; Mechanical properties
\end{abstract}

Contact information: University of Sopron, Simonyi Károly Faculty of Engineering, Wood Sciences and Applied Art, Institute of Wood Based Products and Technologies, H-9400 Sopron, Bajcsy-Zs.E. u. 4.Hungary; *Corresponding author: fatima.zohra.brahmia@phd.uni-sopron.hu

\section{INTRODUCTION}

Over the years, many aspects of building construction have improved, from design to construction materials. There are two well-known kinds of construction, wood construction and concrete construction. For wood construction, the buildings are light and warm during winter. The building material has good resistance to tensile forces, but its resistance to fire is weak (Deplazes 2005). Concrete buildings are heavily constructed and often are tall (Kosmatka et al. 2008). Their resistance to fire is excellent, but the opposite is true for tensile strength, which is considered very small and, in most cases, neglected. Thus, steel reinforcements are used in concrete structures to impart solid bending and tensile force resistance and to protect buildings from seismic activity (Zhang and Sun 2018). For compression strength, concrete is excellent because of the aggregates it contains (Kosmatka et al. 2008). A problem with concrete is that it takes 28 days to reach its maximum strength, and water causes corrosion of the reinforcement steel (Zhang et al. 2017; Marcos-Meson et al. 2018), making buildings weak over time. In addition, cracks are a common problem in concrete (Hillerborg et al. 1976).

Current research has focused on a new material: the cement-wood composite (Frybort et al. 2008). This product has advantages of both concrete and wood. Its resistance to fire is better than that of wood. It has a better tensile and bending strength than concrete, and it is also lighter (Deplazes 2005; Kosmatka et al. 2008). In cement-wood composites, the cement is reinforced by wood fibers, particles, flakes, and wood wool with different shapes and sizes (Ferraz et al. 2012). Cement-wood composites need $24 \mathrm{~h}$ to cure and reach 
maximum strength. As it is lighter than concrete, this type of material is easy to use, equating to time and money saved. These composites are usually used as insulation material or construction material (Quiroga et al. 2016). For construction, cement-wood composite is used as panels, and in some recent studies cement-wood composites were used in the main structural elements of buildings, such as beams (Bejó and Takáts 2005; Frybort et al. 2008). Because of the CWC strength properties, it is usually used for interior and exterior applications and for acoustic properties (e.g., highway sound barriers) (Na et al. 2014). Gunduz at al. (2018) stated that cement-bonded particleboards with composite form are an effective application in term of acoustic outdoor noise barriers.

The most well-known cement bonded products are cement fiberboard, cement bonded particleboard (CPB), wood-wool cement boards (WWCB), and building blocks (Vaickellionis et al. 2006). Low density boards are used as thermal insulation (Frybort et al. 2008). The most important aspect of making cement-wood products is the ratio of the used materials, which are the ratios of wood/cement and cement/water (Phillips and Hse 1987). Compatibility of the wood and cement is important because wood may contain compounds that effect the curing of cement. Curing agent additives are used to solve this problem and make the cement cure in less time.

In most cases, Portland cement is used. Not all wood species exhibit good bonding with cement because each species has different structures and chemical compositions. While the kind of wood important, the place of growth and age can make a difference (Wei et al. 2000; Frybort et al. 2008; Alpár et al. 2011). This is why lots of research has been carried out over the years on this topic with different wood species, kinds of cement, and curing additives, to produce different kinds of cement-wood composites with improvements for many different uses.

The aim of this paper is to summarize the research achievements in improving the hygroscopic (such as thickness swelling and water absorption), mechanical properties (such as bending stress, tensile stress, compression strength, modulus of elasticity, and internal bond), and shortening of the manufacturing time of CWC via pre-treatments and additives. In addition, a new perspective is provided regarding enhancing its fire resistance properties by using fire retardant pre-treatments.

\section{WOOD CEMENT COMPOSITES}

Wood cement composites are one category of the mineral-bonded products. The inorganic-bonded materials first appeared in the early 1900s with gypsum-bonded wood shavings board. In 1910 magnetite-bonded wood board was produced with an approximate density of $400 \mathrm{~kg} / \mathrm{m}^{3}$, and it were developed in Austria in 1914. Such low-density boards are usually used as insulation panels. Cement wood composites appeared in 1920, by manufacturing wood wool cement board (WWCB) with density of $400 \mathrm{~kg} / \mathrm{m}^{3}$. This was followed in 1930 by development of wood chips cement board having a density of 600 $\mathrm{kg} / \mathrm{m}^{3}$, but in that year there was no strong demand for wood cement panels for industrial applications. In 1960 coarse wood particle cement board was made with a density range between 500 to $700 \mathrm{~kg} / \mathrm{m}^{3}$, but in 1970 cement-bonded particle board (CPBP) was developed with very high density 1250 to $1400 \mathrm{~kg} / \mathrm{m}^{3}$. In order to replace asbestos-cement board for structural applications, CPBP was commonly used in Europe for facades, floors, fire, and moisture-resistance furniture (Stokke et al. 2013). Between the 60's and 70's most of researchers focused on the effect of cement/wood proportion on WCP properties; the 
results of such work was widely varied because of the used particle geometry, treatments, wood species, panel density and many other factors (Moslemi and Pfister 1986). In 1990, the cement wood wool board products were further developed, and their density increased to $900 \mathrm{~kg} / \mathrm{m}^{3}$. With the beginning of the 21 st century in 2000 , wood strand cement board (WSCB) were produced with a density of 1000 to $1100 \mathrm{~kg} / \mathrm{m}^{3}$ (Stokke et al. 2013).

The shape of the wood used, i.e. fibers, particles, chopped strands, flakes, or wood wool has an effect on the mechanical properties and utilisation of cement-wood composite products (Mohammed et al. 2016; Hannant et al. 2018). There are several different types of wood cement composites, as shown in Fig. 1.

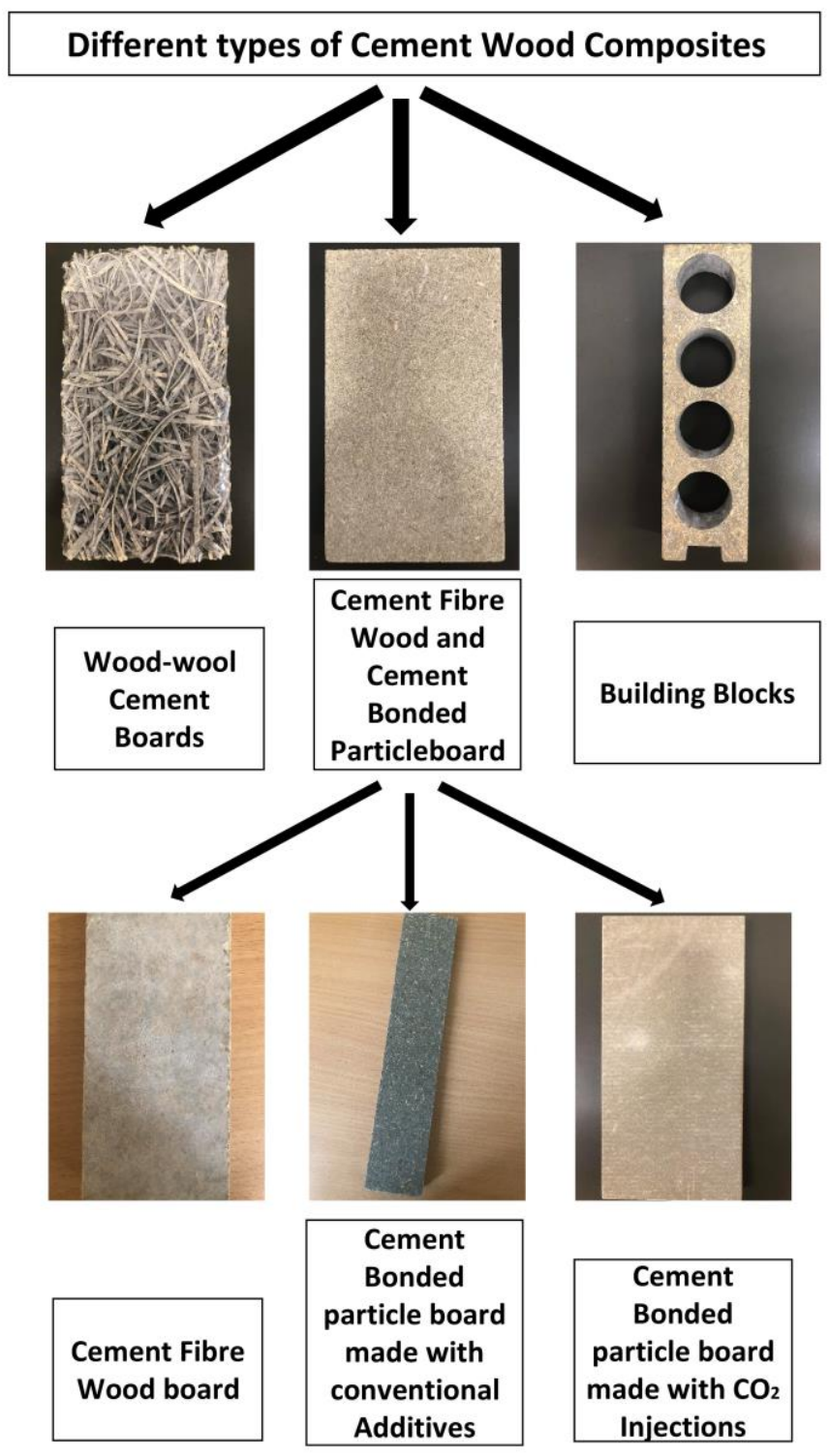

Fig. 1. Schematic diagram of different types of Cement Wood Composites (CWC) 


\section{Cement Fiber Wood and Cement Bonded Particleboard (CPB)}

Cement fiber wood and cement-bonded particleboard usually are produced from fibers and particles of wood with different sizes and shapes (Medved and Resnik 2003). These kinds of boards have good mechanical properties and high weight compared to other cement-wood composites because they have higher density. In recent years, extensive investigation on the possibility of manufacturing particleboard from wood waste has been undertaken. In several studies, $\mathrm{CO}_{2}$ was used as a curing agent for cement particleboard production utilising construction wood waste particles (Soroushian et al. 2013; Wang et al. 2017b). Ashori et al. (2012a) produced boards using waste wood from railway sleepers. The mechanical and physical characteristics of board increased when using $\mathrm{CaCl}_{2}$ or calcium chloride. Wang et al. (2017b) used construction wood waste to produce waterresistant magnesia-phosphate cement particleboards by using red mud and alumina. The results were satisfactory and showed that red mud and wood waste are possible materials for manufacturing particleboard. The manufacture of cement particle board from upcycled wood waste, reinforced by magnesium phosphate, has been investigated. The mechanical characteristics, thermal properties, and water resistance of the board improved (Wang et al. 2018).

\section{Wood-wool Cement Boards (WWCB)}

Wood-wool cement composites are manufactured from Portland cement and wood wool (Koohestani et al. 2016). The fabrication of wood-wool board demands specific particle dimensions. The length varies between 25 and $500 \mathrm{~mm}$, the width from 0.5 to 5 $\mathrm{mm}$, and thickness from 0.03 to $0.64 \mathrm{~mm}$ (Malloney 1989) with density between 400 to $900 \mathrm{~kg} / \mathrm{m}^{3}$. This product has impressive mechanical and chemical properties; however, it is hard to understand why its mechanical properties are so excellent (Koohestani et al. 2016). Usually wood-wool cement boards are used for insulation purposes. Alpár et al. (2011) showed increased bonding between the Portland cement and wood, which improved the product. Additives were used to change the wood fiber surface.

\section{Building Blocks}

These types of products function well as building construction materials. Building blocks have been manufactured by using cement as an adhesive for wood particles. In Washington, blocks that were $203 \mathrm{~mm}$ thick, and either 305 by $610 \mathrm{~mm}$ or 305 by 1280 $\mathrm{mm}$, were produced; however, thickness and height could vary. The biggest blocks weighed $45.5 \mathrm{~kg}$ (Malloney 1989). Building blocks have good resistance to fire and excellent insulation characteristics. Regarding density, they are like soft wood, hence easy to nail and sand. The advantage of building blocks is that they are easy to manufacture (Malloney 1989).

\section{TECHNOLOGY OF CREATING CEMENT WOOD MIXTURE}

For wood-cement composites, the most used cement is Portland cement. Portland cement is a combination of materials heated in a kiln at a specific temperature then ground to make a cement powder (Deplazes 2005; Kosmatka et al. 2008). The Portland cement is $90 \%$ clinker and a small amount of gypsum or calcium sulphate dihydrate $\left(\mathrm{CaSO}_{4} \cdot 2 \mathrm{H}_{2} \mathrm{O}\right)$, magnesium oxide (magnesia) and other minerals, which improve cement characteristics and help the hydration process. The composition is different for each of the five types of 
cement (Kosmatka et al. 2008; Mohammed and Safiullah 2018).

In the hydration of cement, it reacts with water, giving the cement its strength and making it a hard material (Bullard et al. 2011). Usually the compatibility of cement and wood is referred to as the degree of cement setting after mixing it with wood and water. The presence of wood has an effect on the chemical process of cement hardening. Interaction between cement and wood lowers the physical properties of the cement composites. The inhibitor effect is usually measured by the decrease of the heat released during the cement curing. The ratio of the amount of heat released from cement-wood mixture, as well as the heat released from a cement-wood mixture interfaces, is defined as the $C_{\mathrm{A}}$ factor and is used along with $\left(T_{\max }\right)$, or the period of time needed to reach the maximum temperature. In a typical temperature plot of cement-wood mixture, three parts can be defined. It starts with initial temperature rise, followed by the dormant period. At this stage, the temperature is almost constant, stagnant, or barely decreases. The last stage is cement hardening, during which the temperature rapidly increases. Compatibility of cement and wood is divided into three categories: compatible if $C_{\mathrm{A}}>68 \%$, moderately compatible if $68 \%>C_{\mathrm{A}}>28 \%$, or not compatible if $C_{\mathrm{A}}>28 \%$. However, the causes of the incompatibility between wood and cement are unclear (Jorge et al. 2004)

During hydration, all the minerals hydrate simultaneously, making it a complicated process (Liang et al. 2014). Moreover, it is the main reason that the resulting wood and cement bond is very hard. Wood extractives content and type work as inhibitors to cement curing. Wood contains sugars, celluloses, hemicelluloses, and lignin (Frybort et al. 2008; Karade 2010). These substances cause problems during cement curing because they dissolve with the cement compounds, causing changes that prevent the hydration process and make it longer (Jorge et al. 2004). Kochova et al. (2017) studied the effect of saccharides on cement curing. Various organic compounds including fructose, glucose, lignin, sucrose, and cellulose occurring in lignocellulose fibers were added to the cement mixture. Leachate treated fiber was added as well (bagasse, coir, hemp, oil palm, water hyacinth, and spruce wood). The results indicated that the setting time was extended, and the cement curing took 2 days due to the glucose, mannose, and xylose in the leachate treated fiber.

\section{INFLUENCE OF WOOD SPECIES}

Choosing the right wood species depends on the structure of wood and on the kind of wood-cement composites produced. In addition, wood of the same species can have different characteristics because of the place of growth, age, and season of felling the tree. The content of sugars and extractives are different between wood species (Fan et al. 2012). Thus, it is important to choose the right wood species, wood/cement ratio, and the ratio of cement to water because the amount of sugars and extractives affects the cement hydration process (Phillips and Hse 1987). The most common wood species used in wood-cement composites are poplar, or Populus (Ashori et al. 2011; Alpár et al. 2012; Quiroga et al. 2016), and spruce. Spruce is one of the best species for wood-cement composites because it contains small amounts of extractives (Malloney 1989).

Fan et al. (2012) created cement bonded composites from 15 tropical wood species

to investigate their compatibility with Portland cement. The hemicelluloses and carbohydrates of low molecular weight worked as inhibitors for cement hydration in the cement-wood mixture. With an increase in wood ratio, the compatibility between cement 
and wood decayed at different rates depending on the wood species. Species in decreasing order of compatibility of wood and cement can be listed as sapele $97 \%$, nkanang $85 \%$, mvingui $77 \%$, padouk $68 \%$, eyong $64 \%$, tali $50 \%$, iroko $22 \%$, bete $21 \%$, maobi $17 \%$, and doussie $10 \%$. With the increase in solubility content of tropical wood, the compatibility factor increased. Gastro et al. (2019) investigated the compatibility of cement with the following wood species: Eshweilera coriaceae (Ec), Swartzia reanva poepp (Sr), Manilkara amazonica (Ma), and Pouteria guianesisaubl (Pg). These wood species are suitable for CWC production because they had no inhibitory effect on cement hydration and all wood species had a good compatibility factor $C_{\mathrm{A}}=85 \%$ for Ec, $74.4 \%$ for $\mathrm{Sr}, 85 \%$ for $\mathrm{Ma}$ and $76.4 \%$ for $\mathrm{Pg}$. The CWC samples reached their maximum mechanical and physical properties after 28 days. Antiwi-Boasiako et al. (2018) examined the suitability of various tropical wood species for CWC. Triplochiton sclerosylon, Entandrophragma cylindricuim, and Klainedosca gabonensis sawdust were used in CWC production. Based on studying the chemical constituents, their composition, and physico-mechanical properties, Triplochiton sclerosylon had the lowest extractives with $6.12 \%$ of the total extractives, $29.9 \%$ lignin, and $56.4 \%$ holocellulose. It achieved the highest MOR among the used wood species with $696 \mathrm{~N} / \mathrm{m}^{2}$, and it had a moisture absorption value of $8.8 \%$ and outstanding physico-mechanical properties. Wang and $\mathrm{Yu}$ (2012) examined the compatibility of two fast growing species, Chinese fir and poplar, with Portland cement. Results of the hydration test showed that Chinese fir has better compatibility with cement than poplar with $C_{\mathrm{A}}=95 \%$ while poplar has $C_{\mathrm{A}}=24.3 \%$.

Al-Mefarrej (2009) tested the compatibility of five Saudi wood species: lebbeck, button wood, council tree, leucaena, madras thron, and Scots pine with cement. It was found that compatibility factor $C_{\mathrm{A}}$ differed from one wood species to another. Results were as follows: $17.7 \%$ for lebbeck, $52.0 \%$ for button wood, $23.0 \%$ for council tree, $19.0 \%$ for leucaena, $19.9 \%$ for madras thron, and $59.0 \%$ for Scots pine.

Papadopoulos (2009) investigated CBPB made from hornbeam wood. Hydration tests showed that the mixture of cement and hornbeam wood had a moderate inhibition with $39.15 \% C_{\mathrm{A}}$, and two different wood cement ratios, 1:3 and 1:4, were applied. Examination of the board properties confirmed that, except for MOR, all properties improved after increasing the cement to wood ratio. After exposing the CBPB to different fungi, the boards were not affected.

Differences occur even with the same wood species. Kochova et al. (2020) studied wood degradation and its influence on cement-wood compatibility. Two almost identical spruce wood-wool fiber batches were used. The trees were planted, grown, and harvested under the same circumstances. A comparison between the two wood species was made, and results indicated that their compatibility, mechanical strength, and the anatomical structure were different. The $C_{\mathrm{A}}$ factor for spruce sample A was $85 \%$, while that of sample $\mathrm{B}$ was $75 \%$. The flexural strength for A was $4.5 \mathrm{MPa}$, while B was $1.5 \mathrm{MPa}$. The percentage of extractives was also different, as one of the species had more extractives than the other, leading to its incompatibility with cement, and effecting the mechanical properties. As well, storing the wood had an effect on the cement wood compatibility because wood may be attacked by blue stain or other fungi, which leads to an increase in wood extractives. Pasca et al. (2010) studied the compatibility of mountain pine beetle and killed lodgepole pine with Portland cement. A number of factors were involved in the experiment, including: the tree's time of death, sapwood blue stain, white rot, and brown rot. Heat rate, total heat release, and cement hydration were measured, and results showed no difference between fresh and dead mountain pine and beetle killed lodgepole pine. The compatibility 
factor was between $78.9 \%$ and $81.8 \%$. The only incompatibility occurred in case of specimens with white rot, for which $C_{\mathrm{A}}$ was $48.8 \%$; in all other cases excellent physicochemical properties were found. The mixture of cement and blue stained sapwood achieved the highest compatibility.

Based on the cited findings related to the compatibility of wood species and cement, it could be concluded that wood species has huge impact on the quality of the CWC. Wood species divided into three categories according to their $C_{\mathrm{A}}$ : suitable A such as Eshweilera coriaceae, Swartzia reanva poepp, Manilkara amazonica, and Pouteria guianesisaubl, sapele, nkanang, mvingui, Chinese fir, spruce, and mountain pine beetle killed lodgepole pine. Moderately suitable (B) woods included Scots pine, padouk, eyong, tali, lebbeck, madras thron, and hornbeam. Not suitable woods (C) included iroko, bete, maobi, doussie, button wood, council tree, leucaena, and poplar.

\section{EFFECT OF PRE-TREATMENTS ON THE COMPATIBILITY OF CEMENT AND WOOD}

Because wood extractives inhibit cement curing, several studies were conducted to find pre-treatments that reduce the inhibitors in wood, resulting in better compatibility between wood and cement. In most cases, pre-treatment by cold and hot water is applied.

Research was carried out on the compatibility of Portland cement and midribs of date palm (Phoenix dactylifera L). Wood particles were subjected to cold and hot water treatment to enhance their compatibility. Results showed that the untreated wood particles were not suitable for the CBPB, but the compatibility was enhanced with the treatment. Hot water treatment was classified as suitable, and the results also showed that an addition of $3 \% \mathrm{CaCl}_{2}$ enhanced the cement wood compatibility under limited conditions: $T_{\max }=$ $54.2{ }^{\circ} \mathrm{C}$ and $C_{\mathrm{A}}=75.7 \%$ (Nasser and Al-Meffarej 2011). In 2014, a study was made on the compatibility between Portland cement and pre-treated Eucalyptus benthamii wood. Five types of pre-treatments were used: hot water, cold water, sodium hydroxide, $\mathrm{CaCl}_{2}$, and calcium hydroxide. Results indicated that the inhibition effect of the species decreased by $3 \%$ when using $\mathrm{CaCl}_{2}$, which was the best result.

In contrast, the compression strength was increased by mixing $\mathrm{CaCl}_{2}$ with carbonated particles through calcium hydroxide (Gastro et al. 2014). A study was conducted by Quiroga et al. (2016) regarding the influence of wood treatment on the mechanical properties of WCC. Portland cement and Populus euroamericana were used as materials, while water extraction, degradation by alkaline hydrolysis, and retention of inhibitory substances were used as wood treatments. Alkaline hydrolysis was the most effective treatment among the studied treatments for suppressing the inhibitors. However, it resulted in the highest decrease in the mechanical properties of the WCC.

Ferraz et al. (2012) evaluated the chemical compatibility of Portland cement and coir. Cold water, hot water, sodium hydroxide, and $\mathrm{CaCl}_{2}$ were used as pre-treatments. Lignin and holocellulose were inhibitors for cement hydration, but adding a mixture of $\mathrm{NaOH}$ and $\mathrm{CaCl}_{2}$ lowered the inhibition. Jiang et al. (2015) researched the effect of modification methods on the compatibility of poplar leaf fiber and cement. Five methods were used to enhance the compatibility of leaves. The compatibility of leaves and cement can be improved by three methods: dipping the leaf fiber in water, spraying it with sodium silicate, or pure acrylic polymer emulsion. Xie et al. (2016) studied the effect of pretreatment of rice straw on cement curing. The rice straw was pre-treated in different ways: 
untreated, steam exploded, once bleached, and twice bleached. The pre-treatments abolish the amorphous hemicellulose and lignin. In addition, they improve the cement crystallinity and enhance the thermal stability of the rice straw fiber.

Nasser et al. (2016) investigated the possibility of making high quality cementwood composites using tree clipping waste. Different wood species were used, including Acacia salicina, Conocarpus erectus, Ficus altissima, Leucaena glauca, Pithecellobium dulce, and Tamarix aphylla. The wood clipping waste was treated with hot and cold water, and $\mathrm{CaCl}_{2}, \mathrm{Al}_{2}\left(\mathrm{SO}_{4}\right)$, and $\mathrm{MgCl}_{2}$ were used to accelerate the cement curing and enhance compatibility. Results indicated that the wastes could be introduced into the cement wood composite production as an alternative to wood but along with the application of pretreatment and adding $3 \%$ of the additives $\mathrm{CaCl}_{2}, \mathrm{Al}_{2}\left(\mathrm{SO}_{4}\right)$, and $\mathrm{MgCl}_{2}$.

Cechin et al. (2018) studied the compatibility between moso bamboo and Portland cement. The selected wood species were subjected to various pre-treatments such as cold water, hot water, sodium hydroxide, sodium silicate, silane, and calcium chloride. Results indicated that moso bamboo particles had good compatibility with cement, making them suitable for CWC production. Mechanical properties, compatibility, and crystallinity of the produced boards were all enhanced by the used pre-treatments.

Gastro et al. (2018) conducted studies on the correlation between the chemical composition of wood and the cement/wood compatibility. Portland cement II-Z and eight different tropical hardwoods from Amazonia were used for the experiments. No correlation was found between polar and non-polar soluble extractives and cement set inhibitors with the exception of Swartzia recurva with arabinose content. In addition, a correlation was found between Larix with alkaline solution and cement inhibitors. Lignin and hemicellulose created high amounts of degraded polysaccharides, which cause cement inhibition. Five of the used wood species, Eschweilera coriacera, Inga paraensis, Ingalba, Pouteria guianensis and Byrsonima crispa, had low inhibitory effect.

Table 1 presents the compatibility factors of different wood species with different commonly used pre-treatments. The $C_{\mathrm{A}}$ factor was increased by using pre-treatments upgrading wood species from non-suitable to moderate suitable or suitable, but in some cases such as the doussie wood species the pre-treatments has no effect on increasing the cement wood compatibility. Pre-treatments have different effect on each wood species. In most cases hot water and $\mathrm{MgCl}_{2}$ were found to be excellent pre-treatments, but it had no effect on date palm. 
Table 1. Effect of Different Pre-treatments on the Compatibility Factor $C_{\mathrm{A}}(\%)$ of Different Wood Species

\begin{tabular}{|c|c|c|c|c|c|c|c|}
\hline Wood species & \multicolumn{5}{|c|}{ Pre-treatments solutions $\left(\mathrm{C}_{\mathrm{A}} \%\right)$} & & References \\
\hline & None & $\begin{array}{l}\text { Cold } \\
\text { water }\end{array}$ & $\begin{array}{l}\text { Hot } \\
\text { water }\end{array}$ & $\begin{array}{c}\mathrm{CaCl}_{2} \\
3 \%\end{array}$ & $\begin{array}{c}\mathrm{MgCl}_{2} \\
3 \%\end{array}$ & $\mathrm{Ca}(\mathrm{OH})_{2}$ & \\
\hline Chinese fir & 95 & 98.8 & 100 & - & - & - & (Wang and Yu 2012) \\
\hline Poplar & 24.3 & 63.4 & 78.3 & - & - & - & (Wang and Yu 2012) \\
\hline Lebbeck & 17.7 & 42.4 & 48.0 & 73.9 & 81.3 & - & (Al-Mefarrej 2009) \\
\hline Button wood & 52.0 & 77.8 & 82.6 & 87.4 & 90.7 & - & (Al-Mefarrej 2009) \\
\hline Council tree & 22.7 & 65.1 & 62.9 & 77.7 & 76.4 & - & (Al-Mefarrej 2009) \\
\hline Leucaena & 19.0 & 69.9 & 61.3 & 70.4 & 67.0 & - & (Al-Mefarrej 2009) \\
\hline Madras thron & 19.9 & 62.4 & 60.7 & 70.4 & 67.0 & - & (Al-Mefarrej 2009) \\
\hline Scots pine & 59.0 & 81.7 & 86.4 & 90.5 & 92.4 & - & (Al-Mefarrej 2009) \\
\hline Moabi & 17 & - & 92 & 91 & - & 95 & (Fan et al. 2012) \\
\hline Iroko & 22 & - & 52 & 36 & - & 66 & (Fan et al. 2012) \\
\hline Bete & 21 & - & 32 & 30 & - & 43 & (Fan et al. 2012) \\
\hline Tali & 50 & - & 77 & 86 & - & 88 & (Fan et al. 2012) \\
\hline Doussie & 10 & - & 8 & 8 & - & 8 & (Fan et al. 2012) \\
\hline Date palm & 27.8 & 27.8 & 68.7 & 75.8 & 28.3 & - & $\begin{array}{l}\text { (Nasser and Al- } \\
\text { Mefarrej 2011) }\end{array}$ \\
\hline $\begin{array}{l}\text { European } \\
\text { redwood }\end{array}$ & 78.5 & 81.7 & 86.4 & 90.5 & 92.9 & - & $\begin{array}{l}\text { (Nasser and Al- } \\
\text { Mefarrej 2011) }\end{array}$ \\
\hline
\end{tabular}

\section{EFFECT OF ADDITIVES AND WOOD/CEMENT RATIO ON PROPERTIES OF CWC}

Because cement-wood composites are widely used construction materials, their properties are very important. Much effort has been focused on enhancing CWC properties. The wood/cement ratio is one of the foremost influencing factors on CWC (Papadopoulos 2009; Tabarsa and Ashori 2011; Ashori et al. 2012b; Abdelrahman et al. 2015; Boadu et al. 2018). Many additive agents were also utilised as accelerating agents during the hydration process (Frybort et al. 2008). This approach works on bonding the cement and wood, resulting in improvements in the CWC properties. The most used additives have been water glass $\left(\mathrm{Na}_{2} \mathrm{SiO}_{2}\right)$, calcium chloride $\left(\mathrm{CaCl}_{2}\right)$, aluminium silicate $\left(\mathrm{Al}_{2}\left(\mathrm{So}_{4}\right)_{3}\right)$, and magnesium chloride or $\mathrm{MgCl}_{2}$ (Alpár et al. 2011). Some past research work has focused on the injection of carbon dioxide, which was also utilised to help the cement wood bonding.

Ashori et al. (2012b) conducted research on cement-bonded particleboard produced from poplar strands. The wood ratio had an effect on the mechanical and absorption properties of the boards. They became stronger and denser when made with $40 \%$ poplar strands, while also achieving the best bending strength. Mechanical and water absorption properties were improved by adding $7 \%$ calcium chloride $\left(\mathrm{CaCl}_{2}\right)$.

Sotannde et al. (2012) investigated CBPB made from Afzelia African wood. Boards were produced using different additives, cement content, and wood shapes, namely flacks, flacks with saw dust, and saw dust. Increasing the cement content in the wood-cement mixture from 1:2 to 1:3.5, and adding chemical additives decreased the thickness swelling by approx. $60 \%$ and water absorption as well by approx. $71 \%$. The density was increased by approx. 23\%, compressive strength was increased by almost $60 \%$, and internal bonding of the boards by an average of $38 \%$. Only the MOR was not affected by the cement content and additives. The best results were achieved by adding $2 \%$ of $\mathrm{CaCl}_{2}$. The shape of the 
wood particles had an effect on the mechanical properties of the boards. The best results were achieved by flacks with saw dust with $\mathrm{IBS}=0.50 \mathrm{~N} / \mathrm{mm}_{2}, \mathrm{MOR}=11.6 \mathrm{~N} / \mathrm{mm}^{2}$, and $C_{\mathrm{s}}=15.16 \mathrm{~N} / \mathrm{mm}^{2}$, while the worst results were achieved by flacks, with IBS $=0.37 \mathrm{~N} / \mathrm{mm}^{2}$, $\mathrm{MOR}=9.57 \mathrm{~N} / \mathrm{mm}^{2}$, and $C_{\mathrm{s}}=12.6 \mathrm{~N} / \mathrm{mm}^{2}$.

Boadu et al. (2018) investigated CWC board made from extracted sawdust of different tropical hardwood species with differing densities: Triplochiton scleroxylon (low density), Entandrophragma cylindricum (medium density), and Klainedoxa gabonensis (high density). The increase in wood ratio causes an increase in the mechanical and physical properties (MOR, shear strength, and thickness swelling). Boards made from extracted sawdust showed better mechanical properties and resistance to thickness swelling than the boards made from normal sawdust. TS (\%) was decreased from control specimens with TS $=1.5$ and 2.9 for $T$. scleroxylon and $E$. cylindricum, respectively to TS $=0.42$ and 0.95 , respectively, with using hot water. Shear strength was increased from 0.3 and 0 to 1.8 and $1\left(\mathrm{~N} / \mathrm{mm}_{2}\right)$ for $T$. scleroxylon and E. cylindricum, respectively. MOR was increased from 1.8 and 1.1 to 4.1 and $2.4\left(\mathrm{~N} / \mathrm{mm}_{2}\right)$ for $T$. scleroxylon and E. cylindricum, respectively with using extracted sawdust with hot water. CWC boards having high dimensional stability and mechanical properties were produced from extracted wood sawdust of the selected species.

Matoski et al. (2013) studied the influence of various accelerating agents in wood cement panels. WCP was made from the wood dust of various Pinus species and Portland cement. Different additives were used, including calcium chloride, magnesium chloride, aluminium sulphate, and sodium silicate. Results indicated that the chloride additives were able to increase the mechanical properties of the manufactured panel to values above the requirements of the following standards (EN 1058 and ASTM D 1037) with CS $=18.1 \mathrm{MPa}$, bending strength $(\mathrm{BS})=4.72 \mathrm{MPa}$, and IBS $=0.54 \mathrm{MPa}$ for $\mathrm{CaCl}_{2}$, and $\mathrm{CS}=18.0 \mathrm{MPa}$, $\mathrm{BS}=4.55 \mathrm{MPa}$, and IBS $=0.57 \mathrm{MPa}$. For the water absorption test, it was found that aluminium sulphate had the best results, with $\mathrm{WA}=1.52 \%$ after $2 \mathrm{~h}$ of immersion in water and $3.97 \%$ after $24 \mathrm{~h}$, creating a waterproof system by increasing the amount of ions reacting with tricalcium aluminate, which is one of the cement components.

The effect of the pre-treatments and cement-wood ratio on the cement composite has been investigated (Abdelrahman et al. 2015). Prosopis chilensis wood and Portland cement in addition to gypsum as a partial substitution for cement were used for the cement composite production. Cold water, sodium hydroxide, and calcium chloride were used as pre-treatments. CWC were produced with different wood-cement ratios: 2:1, 3:1, 4:1, and $5: 1$. The best wood-cement ratio was 3:1, and adding $10 \%$ of gypsum as partial substitution of cement improves the compression strength with $51.6 \% \mathrm{CS}=51.3 \mathrm{~N} / \mathrm{mm}^{2}$, while for control specimens $\mathrm{CS}=24.8 \mathrm{~N} / \mathrm{mm}^{2}$. However, adding more than $20 \%$ gypsum effected the compression strength negatively.

A study was carried out concerning the hydration behavior of CBPB made from cement and a mixture of wheat straw and poplar. The additives $\mathrm{MgCl}_{2}, \mathrm{CaCl}_{2}$, and $\mathrm{Ca}(\mathrm{OH})_{2}$ were used with different proportions: $3 \%, 5 \%$, and $7 \%$ based on the cement weight. The straw-wood ratio was shown to have a strong influence on the physical and mechanical properties of the CBPB. Among the used additives, $7 \% \mathrm{CaCl}_{2}$ yielded the best results generally for the properties with $\mathrm{TS}=13.4 \%, \mathrm{IBS}=0.66 \mathrm{MPa}$, and $\mathrm{MOR}=16.87 \mathrm{MPa}$ while also shortening the setting time (Nazerian and Sadeghiipanah 2013). Tabarsa and Ashori (2011) investigated the cement wood wool board by using eucalypt and poplar with Portland cement. Ratios of 40:60 and 60:40 of wood wool-cement were used, and $\mathrm{CaCl}_{2}$ was used as treatment. Addition of $5 \% \mathrm{CaCl}_{2}$ increased the performance of the boards. 
Wood species is another factor that determines board properties. For example, boards made of eucalyptus had higher water absorption and shrinking swelling. Cement composite was made from cement and wood wool of kelampyan wood (Anthocephalus chinensis). As additives, 3\% calcium formate, sodium silicate, and magnesium chloride were used to accelerate the setting time of the cement wood composite. The additives increased the early stage strength and mechanical properties of the boards (Mahzabin et al. 2013). Wulf et al. (2015) investigated concrete reinforced by mineralized wood particles as stiffening elements with increasing density. Mixtures of Portland cement and particles of scots pine and spruce were made. To mineralize the wood, various treatments were applied to the wood particles. The wood filler mineralised by water glass (sodium silicate) and Portland cement improved the wood concrete only when using $15 \%$ wood particles as filler based on mass. A density decrease of 36 to $39 \%$ was observed.

\section{TREATMENTS FOR ACCELERATING CEMENT CURING}

Reducing the curing time of the cement wood composites has been heavily researched. Makoving (2010) investigated the possibility of drying WCC boards via microwave without damage to the boards or decreased mechanical properties. The results indicated the possibility of drying the boards without affecting quality. In recent years, $\mathrm{CO}_{2}$ treatment is widely used for decreasing the curing time of the wood cement composite and improving its mechanical properties at the same time.

\section{Carbon Dioxide $\left(\mathrm{CO}_{2}\right)$}

During conventional production, CBPB is pressed between steel plates and left to dry for 24 hours, which is the time needed to become self-supporting. However, carbon dioxide $\left(\mathrm{CO}_{2}\right)$ hardened CBPB in only $5 \mathrm{~min}$, bringing advantages including lower energy requirements and higher production capacity (Alpár et al. 2003). Qi et al. (2010) investigated the possibility of accelerating the hardening of a wood-cement mixture made of red pine and Portland cement using $\mathrm{CO}_{2}$. In the first minutes of using the $\mathrm{CO}_{2}$ injections, the carbonisation reaction started. After 30 min approximately $43 \%$ of the calcium oxide content in the cement was carbonated. The rapid hardening may have been caused by the interaction of calcium silicates in cement with $\mathrm{CO}_{2}$. On the other hand, no reaction was observed between calcium hydroxide and $\mathrm{CO}_{2}$. Wang et al. (2017a) used $\mathrm{CO}_{2}$ curing and fiber reinforcement to accelerate cement curing and enhance the physical properties of particleboard made of cement and wood waste. The results indicated that $\mathrm{CO}_{2}$ helped cement hydration by accelerating the $\mathrm{Ca}(\mathrm{OH})_{2}$ transformation into $\mathrm{CaCO}_{3}$, resulting in improvements in the strength of the particleboard. In addition, the total pore area of 12.2 $\mathrm{m}^{2} \mathrm{~g}^{-1}$ was reduced to $10.3 \mathrm{~m}^{2} \mathrm{~g}^{-1}$ and porosity from $34.8 \%$ to $29.7 \%$. All the requirements of the relevant international standards were fulfilled by enhancing the mechanical properties, dimensional stability, and contaminants sequestration. Soroushian et al. (2013) investigated the effect of accelerated aging on the bending strength; $\mathrm{CO}_{2}$ helps increase the $\mathrm{CaCO}_{3}$ and decrease the $\mathrm{Ca}(\mathrm{OH})_{2}$ content, which results in higher bending strength and stiffness. As a consequence of aging, $\mathrm{CaCO}_{3}$ content increases and $\mathrm{Ca}(\mathrm{OH})_{2}$ content decreases, leading to an improvement in the fiber matrix interfaces.

Increasing the performance of cement wood composite by $\mathrm{CO}_{2}$ is not always effective. The wood species used can have an important effect. Taskirawati et al. (2019) evaluated the characteristics of cement-wood board made of Portland cement and two 
wood species, Acacia mangium (Acacia) and Arthophyllum diversifolium (Lento-lento). The boards were made with the conventional production method, using $\mathrm{CaCl}_{2}$ as an accelerator additive, and boards were also made by the carbonisation method using $\mathrm{CO}_{2}$ injection to accelerate the hardening and enhance the mechanical properties. Results showed that the boards made of Lento-lento wood had better characteristics with the $\mathrm{CO}_{2}$ injection method, while Acacia showed better results with the conventional production method, thereby showing that $\mathrm{CO}_{2}$ injection is not always better than the conventional production methods, depending on the used wood species (Taskirawati et al. 2019).

Maail et al. (2013) studied the degradation of cement-bonded particleboard made of Portland cement and a mixture of wood species: Japanese cypress (Chamaecyparis obtusa Endl.) and Japanese cedar (Cryptomeria japonica D. Don) with $\mathrm{CO}_{2}$ as a curing accelerator. Results indicated the effect of $\mathrm{CO}_{2}$ on the degradation of $\mathrm{CBPB} . \mathrm{CO}_{2}$ helped the boards to reach the maximum mechanical properties in a short time by accelerating the cement curing process. $\mathrm{CO}_{2}$ did not just help in accelerating the curing but also enhanced the mechanical properties and dimensional stability. However, the timing of $\mathrm{CO}_{2}$ treatment had a big influence on its performance. The treatment is recommended for short period of time, no longer than $30 \mathrm{~min}$. Using the $\mathrm{CO}_{2}$ treatment for $60 \mathrm{~min}$ to 10 days had a negative influence on the mechanical properties of the boards, as longer periods of time cause CBPB degradation because of the effect of the calcium carbonated content (Maail et al. 2011). A study was undertaken on cement-wood boards made of Portland cement and date palm with a $\mathrm{CO}_{2}$ curing accelerator. It was found that date palm fibers are not compatible with cement; however, with hot water pre-treatment, the fibers' compatibility was upgraded to suitable. $\mathrm{CO}_{2}$ injection decreased the bending strength and enhanced the matrix and the board's qualities (Hassan et al. 2016).

Additionally, research was done on CBPB made with various kinds of natural fibers using $\mathrm{CO}_{2}$ injection to raise the initial compatibility between cement and fibers. The $\mathrm{CO}_{2}$ injection was successful in increasing the initial strength by accelerating the cement curing and bonding the cement and wood. These boards had similar mechanical properties as the boards made via conventional production, and they had a lower cement content (Marteinsson and Gudmundsson 2018). The durability characteristics of composites made of cellulose fiber and cement were studied. After treating the boards with $\mathrm{CO}_{2}$, results indicated that the capillary porosity decreased due to the $\mathrm{CO}_{2}$ curing, and the rise of $\mathrm{CaCO}_{3}$ content increased the compatibility between the cement and fibers by improving the cement-based matrix for cellulose fibers. The longevity and weathering resistance were also enhanced (Soroushian et al. 2012).

\section{FIRE RESISTANCE OF CEMENT WOOD COMPOSITE}

For building materials, industrial fire resistance is a very important factor. Materials made of magnesium cement products are considered outstanding fire retardant materials (Zuo et al. 2018). Generally, cement-wood composites are materials that have good fire resistance. Saval et al. (2014) investigated the flammability of CBPB made of cement and Oceanic Posidonia waste. Because no flame spread occurred to the CBPB, it is not a flammable material. According to the literature, the cement-wood ratio has an influence on the fire resistance of the cement-wood composites. A study was conducted on recycled Chinese fir particles and cement. The investigation was performed using a cone calorimetry test. Results indicated that the cement-wood ratio had an effect on the fire resistance of the 
CBPB. With a rise in the cement-wood ratio from 0.5 to 2 , the ignition time increased from $26 \mathrm{~s}$ to $548 \mathrm{~s}$, and the mass loss rate decreased.

A number of studies have been conducted on CWC for enhancing its shrinking and swelling, water absorption, and mechanical properties as well as reducing its manufacturing time. However, less research has been aimed at the fire resistance of the CWC. There was no wood pre-treatment investigation performed to improve the fire resistance of $\mathrm{CWC}$, as was the case for reducing wood inhibitors. The only studies in this field concerned the non-combustibility of the material and the effect of wood ratio on fire resistance. Many chemicals could be used as pre-treatments to improve the fire resistance of the wood and as a result improve fire resistance of the wood-cement composite. Sodium silicate is known as a binder and fire retardant that can improve wood properties such as the mechanical properties, dimensional stability, and fire resistance (Medina and Schledjewski 2009; Mahzabin et al. 2013).

Fire retardants have different effects on different materials because each material has a unique response to fire based on a number of factors. For example, the material's ignition ease, rate of burn, and flame spread over the surface are factors to consider. Additionally, the rate at which the flames infiltrate into a wall or barrier, the speed at which heat is released, and the amount of smoke and toxic gas generated all have an effect on the fire resistance of the material (Ayrilmis et al. 2009). However, first, it is important to understand the operation of fire-retardant chemicals, the differences between fire retardants, and to decide which one is better to use depending on the situation.

The fire or flame-retardants are created to decrease the material temperature. When ignition occurs, the flame-retardants create thermal degradation while raising the amount of char and reducing the flammability (LeVan et al. 1990). Fire retardants have two kinds of actions: physical and chemical.

For the physical action, there are many ways to delay ignition. Cooling is one method, and there are some fire retardants that can decrease the materials temperature. Coating is another way of delaying ignition where fire retardants can form a protective layer that prevents the underlying material from combusting. Dilution is the third way in which the retardants release water and carbon dioxide during burning. Each fire retardant has a better effect on a specific kind of material, so the choice of fire retardant depends on the substrate and its unique set of characteristics.

\section{Pre-treatment Fire Retardants}

Many fire retardants could be used for wood pre-treatment in CWC production, such as phosphorus compounds. The most popular phosphorus fire retardant compounds are phosphoric acid and mono and diammonium phosphate salts. In addition, phosphate nitrogen salts containing organic compounds can be taken into consideration (Stevens et al. 2006). Therefore, in general, the phosphorus fire retardants are divided into three categories: those containing inorganic, organic, and halogen components. Their mechanism works in most cases in the solid phases of burning material, but it can be active in the gas phase as well (Van der Veen and de Boer 2012). The phosphorus compounds are efficient as fire retardants because they reduce the thermal degradation of wood (Jiang et al. 2010). The way for the phosphorus chemicals to work as fire retardants is by forming acids that decrease the temperature of the wood (Wu et al. 2002) and as a result increase its dehydration and char formation (Liu 2001; Gao et al. 2006). Char works as a barrier for oxygen and volatile combustible components (VOCs).

Magnesium hydroxide is an interesting fire retardant and stands out among the 
many chemical products because it is environment-friendly, has a low price, low toxicity, corrosiveness, and has smoke suppression abilities (Zhang et al. 2016). At a temperature of around $300{ }^{\circ} \mathrm{C}$, magnesium hydroxide decomposes to magnesium hydroxide with the emission of water vapor, effecting the polymer system (Rothon and Hornsby 1996). In 2017, new research was done on the thermal decomposition of nano-magnesium hydroxide (Yang et al. 2017). Water vapor is released during decomposition, which is how magnesium hydroxide works as a fire retardant as it creates a layer that insulates the material from the flame (Zhu et al. 2016).

Boron, which can be regarded as class of eco-friendly materials (El-Batal et al. 2019), is used in different fields such as agriculture, glass fiber production, or material processing, but most importantly, in fire retardation (Sayan et al. 2010). Boron compounds are the best choice as fire retardants for cellulosic materials. Over the years, research has been carried out showing the effectiveness of boron compounds as fire retardants. In most cases, two kinds are used: borax and boric acid. These two compounds are effective as fire retardants on the surface of wood. In most cases, borax and boric acid are used together because they complement each other. Borax's advantage is in supressing flame propagation, but the disadvantage is that borax promotes smouldering. On the other hand, the boric acid is a good smouldering suppresser but its flame spread suppressing ability is low (Baysal et al. 2007).

As every pre-treatment with fire retardants has a different effect on different wood species, not only the type of fire retardant but also its dosage will have a big influence on the result. Brahmia et al. (2020) studied the effect of different fire retardants of boron and phosphorus compounds with different concentration on poplar and scots pine. Borax with $25 \mathrm{~g} / \mathrm{L}$ concentration, diammonuim hydrogen phosphate with $25 \mathrm{~g} / \mathrm{L}$, and $300 \mathrm{~g} / \mathrm{L}$ concentration, and disodium hydrogen phosphate with $25 \mathrm{~g} / \mathrm{L}$ and $77 \mathrm{~g} / \mathrm{L}$ were used. Results indicated that phosphorus compounds had better performance than borax, especially when used with poplar. Concentration has big influence in the fire resistance performance, with higher concentration giving higher fire resistance. It is recommended to use the fire retardants at high dosage for better results, but in the case of cement wood composites there needs to be a balanced dosage of fire retardants, and their effects on cement wood curing need to be considered.

\section{CONCLUSIONS}

1. Cement wood composites (CWC) are unpredictable building materials that have many influencing factors. The most important factor on CWC production is the compatibility between wood and cement. The wood species is the most important factor in cementwood compatibility because not all species have the same kind and amount of extractives. Not only does the wood species have an effect, but the time of piking, age, and storing make a difference because these factors can influence the extractives within the wood.

2. Pre-treatments for wood have been used to decrease the contents of extractives or cement inhibitors in many studies. The most used wood pre-treatments were hot and cold water, sodium hydroxide, calcium hydroxide, bleach, and alkaline hydrolysis. These pre-treatments can change the cement wood compatibility from non-compatible to suitable. Because of the requirements and regulations, CWC are in continuous 
development.

3. Mechanical properties and reduction of the curing time are the most important aspects that researchers have focused on. Usually mechanical properties are increased by using various additives like calcium chloride and sodium silicate. To decrease the curing time of the CWC, carbon dioxide $\left(\mathrm{CO}_{2}\right)$ is widely used. It is not only used to reduce curing time, but it also improves mechanical properties and water absorption.

4. A few research projects have examined the fire resistance of $\mathrm{CWC}$, and they were mostly focused on demonstrating that suitably formulated CWC are non-combustible materials. Studies also have shown effects of various additives on the thermal stability of the material. Nevertheless, the fire resistance of CWC needs improvement. Pretreatments using fire retardants could be a solution. However, the used fire retardants should not affect the primary properties, such as mechanical performance. In addition, the used fire retardants have to be eco-friendly, as to not harm people. They need to be cheap as well, because the CWC have to remain on budget. The known wood fire retardants that seem to have potential as pre-treatment agents are phosphorus, boron, and magnesium compounds.

\section{ACKNOWLEGMENTS}

The authors extend their gratitude to Prof. Kovacs Zsolt for proofreading the manuscript. This article was made in the frame of the "EFOP-3.6.1-16-2016-00018 Improving the role of research + development + innovation in the higher education through institutional developments assisting intelligent specialization in Sopron and Szombathely." The authors also state that there is no conflict of interest.

\section{REFERENCES CITED}

Abdelrahman, A. B., Parich, M. T., Shah Whid, M., Abdul Samad, A. R., and Ahmed Abdallah, A. M. (2015). "The effects of pre-treatments, wood-cement ratios and partial cement substitution by gypsum on Prosopis chilensis wood composites," European Journal of Wood and Wood Products 73(4), 557-559. DOI:

10.1007/s00107-015-0909-X

Al-Mefarrej, H. A. (2009). "Testing and enhancing the compatibility of five Saudi wood species for cement-bonded particleboard industry," Alexandria Science Exchange Journal 30(3), 333-342.

Alpár, L., T., Pavlekovics, A. A., Csoka, L., and Horvath, L. (2011). "Wood wool cement boards produced with nano minerals," International Scientific Conference on Hardwood Processing (ISCHP2011), 75-82.

Alpar, L. T., Selmeczi, É., and Csoka L. (2012). "Advanced wood cement compatibility with nano mineral," International Scientific Conference on Sustainable Development \& Ecological Footprint, 1-7.

Alpar, L. T., Takáts, P., and Hatano, Y. (2003). "Porosity of cement-bonded particleboards hardened by $\mathrm{CO}_{2}$ injection and cured by hydration," JARQ 37(4), 263268.

Antiwi- Boasiako, C., Ofosuhene, L., and Boadu, K. B. (2018). "Suitability of sawdust 
from three tropical timbers for wood-cement composites," Journal of Sustainable Forestry 37(4), 414-428. DOI: 10.1080/10549811.2018.1427112

Ashori, A., Tabarsa, T., Azizi, Kh., and Mirzabeygi, R. (2011). "Wood-wool cement board using mixture of eucalypt and poplar," Industrial Crops and Products 34(1), 1146-1149. DOI: 10.1016/j.indcrop.2011.03.033

Ashori, A., Tabarsa, T., and Amosi, F. (2012a). "Evaluation of using waste timber railway sleepers in wood-cement composite materials," Construction and Building Materials 126-129. DOI: 10.1016/j.conbuildmat.2011.08.016.

Ashori, A., Tabarsa, T., and Sepahvand, S. (2012b). "Cement-bonded composite boards made from poplar strands," Construction and Building Materials 26(1), 131-134.

DOI: 10.1016/j.conbuildmat.2011.06.001

Ayrilmis, N., Dundar, T., Candan, Z., and Akbulut, T. (2009). "Wettability of fire retardant treated laminated veneer lumber (LVL) manufactured from veneers dried at different temperatures," BioResources 4(4), 1536-1544. DOI:

10.15376/biores.4.4.1536-1544

Baysal, E., Yalinkilic, M. K., Aaltinok, M., Sonmez, A., Peker, H., and Colak, M. (2007). "Some physical, biological, mechanical, and fire properties of wood polymer composite (WPC) pretreated with boric acid and borax mixture," Construction and Building Materials 21(9), 1879-1885. DOI: 10.1016/j.conbuildmat.2006.05.026.

Bejó, L., and Takáts, P. (2005). "Development of cement bonded composite beams," Acta Silvatica Et Lignaria Hungarica 1, 111-119.

Boadu, K. B., Antwi-Boasiako, C., and Ofosuhene, L. (2018). "Solvent extraction of inhibitory substances from three hardwoods of different densities and their compatibility with cement in composite production," Journal of the Indian Academy of Wood Science 15(2), 140-148. DOI: 10.1007/s13196-018-0219-0.

Brahmia, F. Z., Alpár, T., Horváth, P. G., and Csiha, C. (2020). "Comparative analysis of wettability with fire retardants of Poplar (Populus cv. euramericana I214) and Scots pine (Pinus sylvestris)," Surfaces and Interfaces 18, 100405.

Bullard, J. W., Jennings, H. M., Livingston, R. A., Nonat, A., Scherer, G. W., Schweitzer, J. S., Scrivener, K. L., and Thomas, J. J. (2011). "Mechanisms of cement hydration," Cement and Concrete Research 41(12), 1208-1223. DOI:

10.1016/j.cemconres.2010.09.011.

Cechin, L., Matoski, A., Mirand a de lima, A., Monique, A., and Basso, R. (2018). "Effect of treatments on high initial strength Portland cement and mosso bamboo compatibility," Revista Ingenieria de Construction 33(2), 127-136.

Deplazes, A. (2005). "Constructing architecture materials processes structures," Bikhauser-Publishers for Architecture, 60-112.

El-Batal, A. I., El-Sayyad, G. S., Al-Hazmi, N. E., and Gobara, M. (2019). “Antibiofilm and antimicrobial activities of silver boron nanoparticles synthesized by PVP polymer and gamma rays against urinary tract pathogens," Journal of Cluster Science, 30(4), 947-964.

Fan, M., Nadikontar, M. K., Zhou, X., and Ngamveng, J. N. (2012). “Cement-bonded composites made from tropical woods: Compatibility of wood and cement," Construction and Building Materials 36, 135-140. DOI: 10.1016/j.conbuildmat.2012.04.089.

Ferraz, J. M., Del Menezzi, C. H. S., Sarza, M. R., Okino, E. Y. A., and Martinz, S. A. (2012). "Compatibility of pretreated coir fibers (Cocos nucifera L.) with Portland cement to produce mineral composites," International Journal of Polymer Science 
2012, 1-15. DOI: 10.1155/2012/290571

Frybort, S., Maurtiz, R., Teischinger, A., and Müller, U. (2008). "Cement bonded composites - A mechanical review," BioResources 3(2), 602-626. DOI: 10.15376/biores.3.2.602-626

Gao, F., Tong, L. and Fang, Z. (2006). "Effect of a novel phosphorous-nitrogen containing intumescent flame retardant on the fire retardancy and the thermal behaviour of poly(butylene terephthalate)," Polymer Degradation and Stability 91(6), 1295-1299. DOI: 10.1016/j.polymdegradstab.2005.08.013

Gastro, V., Araujo, R. D., Parchen, C., and Iwakiri, S. (2014). "Evaluation of pretreatment effect of eucalyptus benthami maiden and cambage wood on the compatibility degree with portland cement," Revista Arvore 35(5), 935-942.

Gastro, V., Da rosa, R., Zambuja, A., Bila, N. F., Parchen, C. F. A., Saassaki, G. I., and Iwkiri, S. (2018). "Correlation between chemical composition of tropical hardwoods and wood-cement compatibility," Journal of Wood Chemistry and Technology 38(1), 28-34. DOI: 10.1080/02773813.2017.1355390

Gastro, V., Zambuja, R. D. R., Parchen, C. F. A., and Iwakiri, S. (2019). "Alternative vibro- dynamic compression processing of wood-cement composites using Amazonian wood," Acta Amazonia 49(1), 75-80.

Gunduz, L., Kalkan, S. O., and Isker, A. M. (2018). "Effects of using cement-bonded particle boards with a composite component in terms of acoustic performance in outdoor noise barriers," The Eurasia Proceedings of Science Technology Engineering and Mathematics (4), 246-255.

Hannant, D. J., Venkata, S. B., Siver, and Sreekanth, P. S. R. (2018). "5.15 Cementbased composites," Comprehensive Composite Materials II 5, 379-420.

Hassan, M. S., Salih, S. A., and Ali, I. M. (2016). "Strength evaluation of CO2-cured cellulose date palm fiber reinforced cementitious boards," Eng. and Tech. Journal 34, 1029-1046.

Hillerborg, A., Modéer, M., and Petersson, P. E. (1976). "Analysis of crack formation and crack growth in concrete by means of fracture mechanics and finite elements," Cement and Concrete Research 6(6), 773-781. DOI: 10.1016/0008-8846(76)90007-7.

Jiang, D., Cui, S., Xu, F., and Tuo, T. (2015). "Impact of leaf fiber modification methods on compatibility between leaf fibers and cement-based materials," Construction and Building Materials 94, 502-512. DOI: 10.1016/j.conbuildmat.2015.07.045

Jiang, J., Li, J., Hu, J., and Fan, D. (2010). "Effect of nitrogen phosphorus flame retardants on thermal degradation of wood," Construction and Building Materials 24(12), 2633-2637. DOI: 10.1016/j.conbuildmat.2010.04.064

Jorge, F. C., Pereira, C., and Ferreira, J. M. F. (2004). "Wood-cement composites: A review," Holz als Roh - und Werkstoff 62(5), 370-377. DOI: 10.1007/s00107-0040501-2

Karade, S. R. (2010). "Cement-bonded composites from lignocellulosic wastes," Construction and Building Materials 24(8), 1323-1330. DOI:

10.1016/j.conbuildmat.2010.02.003

Kochova, K., Capri, V., Gauvin, F., and Schollbach, K. (2020). "Investigation of local degradation in wood stands and its effect on cement wood composites," Construction and Building Materials 231, 117201. DOI: 10.1016/j.conbuildmat.2019.117201

Kochova, K., Schollbach, K., Gauvin, F., and Browers, H. J. H. (2017). "Effect of saccharides on the hydration of ordinary Portland cement," Construction and Building Materials 150, 268-275. DOI: 10.1016/j.conbuildmat.2017.05.149 
Koohestani, B., Koubaa, A., Belem, T., Bussière, B., and Bouzahzah, H. (2016). "Experimental investigation of mechanical and microstructural properties of cemented paste backfill containing maple-wood filler," Construction and Building Materials 121, 222-228. DOI: 10.1016/j.conbuildmat.2016.05.118

Kosmatka, S. H., Kerkhoff, B. and Panarese, W. C. (2008). "Design and control design and control of concrete mixture," Engineering Bulletin 001, 1-228.

LeVan, S. L., Ross, R. J. and Winandy, J. E. (1990). Effects of Fire Retardant Chemicals on the Bending Properties of Wood at Elevated Temperatures, U.S. Department of Agriculture, Forests Product Laboratory, Madison, WI, USA.

Liang, Z. F., Yang, B., Wang, L., Zhang, X., Zhang, L., and He, N. (2014). "Evolving flexible neutral tree model for portland cement hydration process," Advances in Swarn intelligence 302-309.

Liu, Y. L. (2001). "Flame-retardant epoxy resins from novel phosphorus-containing novolac," Polymer 42(8), 3445-3454. DOI: 10.1016/S0032-3861(00)00717-5

Maail, R. S. (2013). "Degradation analysis on manufacture of cement bonded particleboard using supercritical $\mathrm{CO}_{2}$," Wood Research Journal 4(2), 76-82.

Maail, R. S., Umemura, K., Aizawa, H., and Kanai, S. (2011). "Curing and degradation processes of cement-bonded particleboard by supercritical $\mathrm{CO}_{2}$ treatment," Journal of Wood Science 57(4), 302-307. DOI: 10.1007/s10086-011-1179-9

Mahzabin, S., Hamid, R., and Badaruzzaman, W. H. W. (2013). "Evaluation of chemicals incorporated wood fiber cement matrix properties," Journal of Engineering Science and Technology 8(4), 385-398.

Makoving, I. (2010). "Microwave drying of wood cement composites," Wood Research 55(2), 115-124.

Malloney, T. M. (1989). "Composition board materials: properties and testing of modern particle and dry process fiberboard," Manufacturing 120-128.

Marcos-Meson, V., Michel, A., Solgaard, A., Fischer, G., Edvardsen, C., and Skovhus, T. L. (2018). "Corrosion resistance of steel fiber reinforced concrete - A literature review," Cement and Concrete Research 1-20. DOI:

10.1016/j.cemconres.2017.05.016

Marteinsson, B., and Gudmundsson, E. (2018). "Cement bonded particle boards with different types of natural fibers - using carbon dioxide injection for increased initial bonding," Open Journal of Composite Materials 8(1), 28-42. DOI: 10.4236/ojcm.2018.81003

Matoski, A., Hara, M. M., Iwakiri, S., and Casabi, J. M. (2013). "Uso de aditivos aceleradores em painéis de cimento-madeira: Características e propriedades," Acta Scientiarum - Technology 35(4), 655-660. DOI: 10.4025/actascitechnol.v35i4.11261

Medina, L. A., and Schledjewski, R. (2009). "Water glass as hydrophobic and flame retardant additive for natural fiber reinforced composites," Journal of Nanostructured Polymers and Nanocomposites 5(4), 107-114.

Medved, S., and Resnik, J. (2003). "Influence of beech particle size used in surface layer on bending strength of three-layer particleboard," Zbornik Gozdarstva in Lesarstva, 72, 197-207.

Mohammed, A., Abdallah, A., and Yassin abdelgadir, A. (2016). "Effect of cement/ wood ratio and particle size on some properties of acaci nilotica wood-cement aggregates," Sudan Silva 12(i), 41-52.

Mohammed, S., and Safiullah, O. (2018). "Optimization of the $\mathrm{SO}_{3}$ content of an Algerian Portland cement: Study on the effect of various amounts of gypsum on 
cement properties," Construction and Building Materials 164, 362-370. DOI: 10.1016/j.conbuildmat.2017.12.218

Moslemi, A. A., and Pfister, S. C. (1986). "The influence of cement/wood ratio and cement type on bending strength and dimensional stability of wood-cement composite panels," Wood and Fiber Science 19(2), 165-175.

Na, B., Wang, Z., Wang, H., and Lu, X. (2014). "Wood-cement compatibility review," Wood Research 59(5), 813-826.

Nasser, R. A., and Al-Mefarrej, H. A. (2011). "Midribs of date palm as a raw material for wood-cement composite industry in Saudi Arabia," World Applied Science Journal 5(12), 1651-1658.

Nasser, R. A., Salem, M. Z. M., Al-Meferrej, H. A., and Aref, I. M. (2016). "Use of tree pruning wastes for manufacturing of wood reinforced cement composites," Cement and Concrete Composites 72, 246-256. DOI: 10.1016/j.cemconcomp.2016.06.008

Nazerian, M., and Sadeghiipanah, V. (2013). "Cement-bonded particleboard with a mixture of wheat straw and poplar wood," Journal of Forestry Research 24(2), 381390. DOI: $10.1007 / \mathrm{s} 11676-013-0363-8$

Papadopoulos, A. N. (2009). "Physical mechanical properties and durability against basidiomycetes of particleboards made from cement and Carpinus betulus L. wood particles," Wood Research 54(2), 95-100.

Pasca, S. A., Hartly, I. D., Reid, M. E., and Thring, R. W (2010). "Evaluation of compatibility between beetle-killed lodgepole pine (Pinus contorta var. Latifolia) wood with Portland cement," Materials 3(12), 5311-5319. DOI: 10.3390/ma3125311

Phillips, D. R., and Hse, C. Y., (1987). "Effect of cement / wood ratios and wood storage conditions on hydration temperature, hydration time, and compressive strength of wood-cement mixtures," Wood and Fiber Science 19(3), 262-268.

Qi, H., Cooper, P. A., and Hooton, D. (2010). "The investigation of basic processes of rapidly hardening wood-cement-water mixture with $\mathrm{CO}_{2}$," European Journal of Wood and Wood Products 68(1), 35-41. DOI: 10.1007/s00107-009-0351-z

Quiroga, A., Marzocchi, V., and Rintoul, I. (2016). "Influence of wood treatments on mechanical properties of wood-cement composites and of Populus Euroamericana wood fibers," Composites Part B: Engineering 84, 25-32. DOI: 10.1016/j.compositesb.2015.08.069

Rothon, R. N. and Hornsby, P. R. (1996). "Flame retardant effects of magnesium hydroxide," Polymer Degradation and Stability 54(2-3 SPEC. ISS.), 383-385. DOI: 10.1016/s0141-3910(96)00067-5

Saval, J. M., Lapuenta, R., Navarro, V., and Tenza-Abril, A. J. (2014). "Fire-resistance, physical and mechanical characterization of particle board containing oceanic Posidonia waste," Mater. Construc. 64, 314. DOI: 10.3989/mc.2014.01413

Sayan, P., Sargut, S. T. and Kiran, B. (2010). "Effect of impurities on the microhardness of borax decahydrate," Powder Technology 197(3), 254-259. DOI: 10.1016/j.powtec.2009.09.025

Soraushian, P., Wan, J. P., and Hassan, M. (2012). "Durability characteristics of CO 2cured cellulose fiber reinforced cement composites," Construction and Building Materials 34, 44-53. DOI: 10.1016/j.conbuildmat.2012.02.016

Soroushian, P., Won, J. P., and Hassan, M. (2013). "Durability and microstructure analysis of CO2-cured cement-bonded wood particleboard," Cement and Concrete Composites 41, 34-44. DOI: 10.1016/j.cemconcomp.2013.04.014

Sotannde, A., Olwwadare, A. O., Ogedoh, O., and Adeogun, P. F. (2012). "Evaluation of 
cement-bonded particle board produced from Afzelia africana wood residues," Journal of Engineering Science and Technology 7(6), 732-743.

Stevens, R. van Es, D. S., Bezemer, R. C., and Kranenbarg, A. (2006). "The structureactivity relationship of fire retardant phosphorus compounds in wood," Polymer Degradation and Stability 91(4), 832-841. DOI:

10.1016/j.polymdegradstab.2005.06.014

Stokke, D. D., Wu, Q., and Han, G. (2013). " Introduction to wood and natural fiber composites," Wiley Series in Renewable Resources, Belgium, 225-226.

Tabarsa, T., and Ashori, A. (2011). "Dimensional stability and water uptake properties of cement-bonded wood composites," Journal of Polymers and the Environment 19(2), 518-521. DOI: 10.1007/s10924-011-0295-3

Taskirwati, I., Sanusi, D., Baharudin, B., Agussalim, A., and Suhasman, S. (2019). "Characteristics of cement board with $\mathrm{CO}_{2}$ injection method added $\mathrm{CaCl} 2$ as additive using two wood species from community forests," IOP Conference Series: Earth and Environmental Science 270(1). DOI: 10.1088/1755-1315/270/1/012055

Vaickellionis, G., and Vaickellionis, R. (2006). "Cement hydration in the presence of wood extractives and pozzolan mineral additives," Ceramics-Silikáty 50(2), 115-122

Van der Veen, I. and de Boer, J. (2012). "Phosphorus flame retardants: Properties, production, environmental occurrence, toxicity and analysis," Chemosphere 88(10), 1119-1153. DOI: 10.1016/j.chemosphere.2012.03.067

Wang, L., Chen, S. S., Tsang, D. C. W., Poon, C. S., and Dai, J. G. (2017a). “CO2curing and fiber reinforcement for green recycling of contaminated wood into highperformance cement-bonded particleboards," Journal of $\mathrm{CO}_{2}$ Utilization 18, 107-116. DOI: $10.1016 /$ j.jcou.2017.01.018

Wang, L., Yu, I. K. M., Tsang, D. C. W., Li, S., Li, J., Poon, C. S., Wang, Y. S., and Dai, J. G. (2017b). "Transforming wood waste into water-resistant magnesia-phosphate cement particleboard modified by alumina and red mud," Journal of Cleaner Production 452-462. DOI: 10.1016/j.jclepro.2017.09.038

Wang, L., Yu, I. K. M., Tsang, D. C. W., Yu, K., Li, S., Poon, C. S., and Dai, J. G. (2018).'Upcycling wood waste into fiber-reinforced magnesium phosphate cement particleboards," Construction and Building Materials 159, 54-63. DOI: 10.1016/j.conbuildmat.2017.10.107

Wang, X., and Yu, Y. (2012). "The compatibility of two common fast-growing species with Portland cement." Journal of the Indian Academy of Wood Science, 9(2), 154159.

Wei, Y. M., Guang Zhou, Y., and Tomita, B. (2000). "Hydration behavior of wood cement-based composite I: Evaluation of wood species effects on compatibility and strength with ordinary portland cement," Journal of Wood Science 46(4), 296-302. DOI: $10.1007 / \mathrm{BF} 00766220$

Wu, C. S., Liu, Y. L. and Chiu, Y. S. (2002). "Epoxy resins possessing flame retardant elements from silicon incorporated epoxy compounds cured with phosphorus or nitrogen containing curing agents," Polymer 43(15), 4277-4284. DOI: 10.1016/S0032-3861(02)00234-3

Wulf, F., Schulz, K., Brosel, L., and Pfriem, A. (2015). “Armirani beton s mineraliziranim česticama drva kao element za ukrućenje smanjene gustoće," Drvna Industrija 66(1), 57-62. DOI: 10.5552/drind.2015.1345

Xie, X., Gou, G., Zhou, Z., Jiang, M., Xu, X., Wang, Z., and Hui, D. (2016). 'Influence of pre-treatment of rice straw on hydration of straw fiber filled cement based 
composites," Construction and Building Materials 113, 449-455. DOI:

10.1016/j.conbuildmat.2016.03.088

Yang, W., Zhu, Z., Shi, J., Zhao, B., Chen, Z., and Wu, Y. (2017). "Characterizations of the thermal decomposition of nano-magnesium hydroxide by positron annihilation lifetime spectroscopy," Powder Technology 311, 206-212. DOI:

10.1016/j.powtec.2017.01.059

Zhang, K., and Sun, Q. (2018). "The use of wire mesh-polyurethane cement (WM-PUC) composite to strengthen RC T-beams under flexure," Journal of Building Engineering 122-136. DOI: 10.1016/j.jobe.2017.11.008

Zhang, T., Liu, W., Wang, M., Liu, P., Pan, Y., and Liu, D. (2016). "Synergistic effect of an aromatic boronic acid derivative and magnesium hydroxide on the flame retardancy of epoxy resin," Polymer Degradation and Stability 130, 257-263. DOI: 10.1016/j.polymdegradstab.2016.06.011

Zhang, X., Wang, L., Zhang, J., Ma, Y., and Lui., Y. (2017). "Flexural behavior of bonded post-tensioned concrete beams under strand corrosion," Nuclear Engineering and Design 313, 414-424. DOI: 10.1016/j.nucengdes.2017.01.004

Zhua, D., Naia, X., Lan, S., Bian, S., Liu, X., and Li, W. (2016). "Surface modification of magnesium hydroxide sulfate hydrate whiskers using a silane coupling agent by dry process," Applied Surface Science 390, 25-30. DOI: 10.1016/j.apsusc.2016.08.033

Zuo, Y., Xiao, J., Wang, J., Liu, W., Li, X., and Wang, Y. (2018). "Preparation and characterization of fire retardant straw/magnesium cement composites with an organic-inorganic met work structure," Construction and Building Materials 171, 404-413. DOI: 10.1016/j.conbuildmat.2018.03.111

Article submitted: March 9, 2020; Peer review completed: May 24, 2020; Revised version received: June 22, 2020; Accepted: June 27, 2020; Published: July 1, 2020.

DOI: 10.15376/biores.15.3.Brahmia 